\title{
Exploring Validated Self-Reported Instruments to Assess Adherence to Medications Used: A Review Comparing Existing Instruments
}

\author{
Razan Izzat Nassar (D)', Iman Amin Basheti (D)', Bandana Saini $\mathbb{D}^{2}$ \\ 'Department of Clinical Pharmacy and Therapeutics, Faculty of Pharmacy, Applied Science Private University, Amman, Jordan; ${ }^{2}$ College of Pharmacy, \\ The University of Sydney, Sydney, NSW, Australia \\ Correspondence: Iman Amin Basheti, Department of Clinical Pharmacy and Therapeutics, Faculty of Pharmacy, Applied Science Private University, \\ Amman, II93I, Jordan, P. O. Box 166, Email dr_iman@asu.edu.jo
}

Objective: To provide an overview of instruments that measure adherence to medications to facilitate selection of an instrument and to provide a summary of some published adherence assessment tools tailored to be used by the healthcare team, especially the pharmacists. Data Sources: Studies were identified via PubMed, Medline, Embase, and Google Scholar using the search terms medication adherence, compliance, persistence, combined with the terms questionnaire, scale, survey, self-report, and instrument.

Study Selection: Articles written in English, describing questionnaire instruments that were psychometrically evaluated (reporting a good coefficient of internal consistency, reliability assessed through Cronbach's alpha, and had been validated against a subjective or objective measure), and containing 30 or fewer items were included.

Data Synthesis: Twelve instruments were identified and included in this review. Instruments were reviewed by evaluating specific characteristics (number of items, sample size, reliability, sensitivity, specificity, questionnaire completion time, criterion validity, and component analysis).

Conclusion: Various instruments are used to assess patient adherence to medications; however, no single one performs well on all criteria. Every instrument has different advantages and unique properties. A particular instrument can be chosen after considering certain factors, such as the specific requirements, population, the needed time to complete the questionnaire, the sensitivity, and the specificity of the questionnaire. Moreover, there is a recognized need to provide primary care medication adherence services customized to patient's needs. A link for teamwork between healthcare providers such as pharmacists and patients is needed. This link can be a validated instrument to assess patient's adherence to medication.

Keywords: adherence to medications, compliance, questionnaire, self-report, scale, survey, instrument

\section{Introduction}

Adherence is commonly defined as the degree to which patients follow medical advice and take their medications according to the way prescribed by the healthcare team. ${ }^{1,2}$ There is an increasing focus on medication adherence research, partly due to the evidence highlighting the extent and consequences of sub-optimal adherence. These issues are widespread, applicable not only to a specific disease but across the spectrum of chronic diseases, resulting in significant health and cost sequelae associated with non-adherence. ${ }^{3}$

Non-adherence is a phenomenon with different observable patterns, across patients, and even within the same patient for different treatments. The most commonly observed patterns are categorized into intentional non-adherence (deliberate non-adherence which is associated with patients' beliefs, where patients usually decide not to take their medications), and unintentional non-adherence (unplanned behavior which is associated with lack of resources). ${ }^{4,5}$ Non-adherence research indicates an extensive range of potential determinants or factors, which may be categorized into patient-related factors, physician or healthcare system-related factors, medication-related factors, and external factors. ${ }^{6-8}$ Among chronic illnesses, only half of the patients take their medications as prescribed by their doctors or by the healthcare team. ${ }^{7}$ 
It is necessary to measure patients' adherence with valid and reliable instruments; ${ }^{9}$ indeed several methods are used to assess adherence. These methods are delineated into direct and indirect methods. Each method has its own advantages and disadvantages. ${ }^{10,11}$ Direct methods include observational measures and biological markers while indirect methods include self-reported questionnaires, pharmacy refill records, pill count, and electronic monitoring systems. ${ }^{12}$ However, to date, no method has been nominated as a universal gold standard method $;{ }^{13}$ but generally, self-reported adherence questionnaires are the most used method to assess patient adherence to medications for clinical use. ${ }^{14}$ Self-report measures offer several advantages, including low cost, ability to differentiate between intentional and unintentional non-adherence, noninvasiveness, and ease of administration. Self-report measures if devised well can also provide some extra information such as reasons behind non-adherence, beliefs about medications, and patient understanding of medications regimens. ${ }^{14-16}$

As prescribers, physicians often have scarce time for exploring adherence, and thus would do well to emphasize the availability of other educational resources/health professionals, including but not limited to pharmacists. ${ }^{7}$ Pharmacists are uniquely positioned to deliver customized patient-oriented services that would ensure that patients are taking their medications in adherence with the healthcare team instructions; due to the fact that they interact with almost every outpatient. ${ }^{17}$ Moreover, in case of chronic diseases, the pharmacist dispenses repeat prescriptions, giving them the sole chance to reassess patient's adherence to medication and to re-educate the patients regarding any medication or regarding the importance of adhering to their medications. ${ }^{7,17-21}$

This review aims to present a data summary for healthcare providers generally, and pharmacists specifically, regarding utilizable adherence assessment instruments (self-reported questionnaire) that can be used at the point of care.

\section{Literature Review}

Studies reporting the development and validation of adherence instruments were identified through PubMed, Medline, Embase, and Google Scholar using the search terms medication adherence, compliance, persistence, combined with the terms questionnaire, scale, survey, self-report, and instrument. Our literature review identified some medication adherence instruments; however, we focused to provide a data summary for healthcare providers generally, and pharmacists specifically, regarding utilizable adherence assessment instruments that can be used at the point of care. As there are no existing criteria regarding instrument (questionnaire) selection; the research team developed a certain criterion to help pharmacists in the instrument selection process. Our criteria included instruments written in English, containing 30 or fewer items (practical to use at the point of care), ${ }^{22}$ describing scales/instruments which were psychometrically evaluated (reported a good coefficient of internal consistency, reliability assessed through Cronbach's alpha, and had been validated against a subjective or objective measure).

Instruments meeting the inclusion criteria were collated and data such as the number of the items in the instrument, the sample size, reliability, sensitivity, specificity, questionnaire completion time, and criterion validity were extracted and summarized. The study selection process is illustrated in Figure 1. Twelve instruments were identified and included in this review.

\section{Data Synthesis}

The selected instruments $(\mathrm{n}=12)$ pertaining to usable adherence assessment instruments are listed in Table 1 . The number of scale items varies widely from four to 30 items. ${ }^{23-25}$ Some of the instruments were developed with a small sample size (43 patients), such as the Brief Medication Questionnaire (BMQ), in contrast, other instruments were developed and tested in a relatively large sample size (1,009 patients), such as the Test of the Adherence to Inhalers (TAI). ${ }^{26,27}$

The reliability of the instruments, measured using Cronbach's Alpha coefficient, ranged from 0.61 for the Morisky Medication Adherence Scale (MMAS-4) to 0.93 for the Drug Attitude Inventory scale (DAI). ${ }^{23,28}$ Generally, scales with a coefficient higher than 0.7 are considered sufficient to indicate adequate internal consistency. ${ }^{29}$

The sensitivity of the instruments (the ability of the questionnaire to detect true non-adherence) ranged from 0.63 in the Pediatric Inhaler Adherence Questionnaire (PIAQ) to 0.848 in the TAI (when the cut-off score was 45). ${ }^{27,30}$

As for specificity (the ability of the questionnaire to correctly identify those patients who are not facing adherence problems) ranged from 0.226 in the TAI (when the cut-off score was 45) to 1.0 in the BMQ (for the regimen screen section) and 0.9 in the PIAQ. ${ }^{26,27,30}$ Five instruments did not report the sensitivity nor the specificity. 
Potentially relevant articles identified from broad search of the literature and screened $(n=43)$

Articles excluded $(\mathrm{n}=25)$ :

- $\quad$ No full text available $(n=7)$

- Focus not on development or validation of an adherence scale $(\mathrm{n}=15)$

- Article not in English $(\mathrm{n}=3)$

Articles excluded $(n=6)$ :

- No numeric data for extraction $(n=4)$

- The instrument was not validated $(\mathrm{n}=2)$

Articles included in the review $(\mathrm{n}=12)$

Figure I Flow chart of study selection process.

The methods used to assess the criterion validity of each instrument varied widely from one to another; some instruments used subjective validation (therapist report) such as the DAI, while other instruments choose an objective method to assess validity (Medication Event Monitoring Systems (MEMS)) such as the BMQ and the Brief Adherence Rating Scale BARS. ${ }^{24,26,28}$

\section{The Drug Attitude Inventory Questionnaire (DAI)}

The DAI was developed based on literature review and patient reports to understand the schizophrenic patient's perception of drug treatment. ${ }^{28}$ It has some limitations since it measures attitude instead of behavior, it classifies patients as compliers and non-compliers, which does not concede the complexity of compliance, it was also validated based only on the therapist's judgment and they may overestimate compliance. ${ }^{31}$

\section{Morisky Medication Adherence Scale (MMAS-4)}

The MMAS-4 is a widely used questionnaire instrument to assess adherence, and the most adaptable one at the point of care because it is short, simple, easy to score, and it also can identify barriers. ${ }^{22,23}$ However, it does not provide any information on unintentional non-adherence, ${ }^{27}$ and it is comparatively short and mainly suitable for initial screening. ${ }^{32}$ It has been validated in the broadest range of diseases such as heart failure and coronary artery disease, the type two diabetes, dyslipidemia, parkinson's disease, depression, and human immunodeficiency virus infection. ${ }^{22}$

\section{The Brief Medication Questionnaire (BMQ)}

The BMQ was developed based on literature review and patient feedback, it is divided into three main question headings; the regimen screen, the belief screen, and the recall screen; it also has multiple sub-questions. ${ }^{26}$ It can assess self-efficacy, which is defined as the individual's belief that he/she can successfully complete a specific action to produce a desired 
Table I Comparison Between Different Types of Questionnaires

\begin{tabular}{|c|c|c|c|c|c|c|c|c|c|}
\hline $\begin{array}{l}\text { Questionnaire } \\
\text { Name }\end{array}$ & $\begin{array}{l}\text { Number } \\
\text { of Items }\end{array}$ & Sample Size & Reliability & Sensitivity & Specificity & $\begin{array}{l}\text { Questionnaire } \\
\text { Completion } \\
\text { Time }\end{array}$ & Criterion Validation & Country & $\begin{array}{l}\text { Primary } \\
\text { Reference }\end{array}$ \\
\hline $\begin{array}{l}\text { Drug Attitude } \\
\text { Inventory } \\
\text { (DAI) }\end{array}$ & $\begin{array}{l}\text { The } \\
\text { original } \\
\text { form } \\
\text { consists of } \\
30 \text { true or } \\
\text { false items } \\
\text { The } \\
\text { modified } \\
\text { form } \\
\text { consists of } \\
10 \text { true or } \\
\text { false items }\end{array}$ & $\begin{array}{l}150 \text { schizophrenic } \\
\text { patients }(93 \text { were males), } \\
\text { the males mean age }= \\
40.0(\mathrm{SD}=12.4) \text {, while } \\
\text { the female mean age }= \\
42.1(\mathrm{SD}=10.8)\end{array}$ & $\begin{array}{l}\alpha=0.93 \\
\text { Test- retest reliability } \\
\text { (after } 4 \text { weeks) } \\
\alpha=0.82\end{array}$ & $0.72^{41}$ & $0.63^{41}$ & Not reported ${ }^{41}$ & Therapist Decision ${ }^{41}$ & Canada & [28] \\
\hline $\begin{array}{l}\text { Morisky } \\
\text { Medication } \\
\text { Adherence } \\
\text { Scale (MMAS- } \\
\text { 4) }\end{array}$ & 4 items & $\begin{array}{l}290 \text { patients }(70 \% \text { were } \\
\text { females), their mean age } \\
=54\end{array}$ & $\alpha=0.61$ & 0.81 & 0.44 & Not reported ${ }^{41}$ & $\begin{array}{l}\text { Clinical outcome (Blood } \\
\text { pressure) }\end{array}$ & USA & [23] \\
\hline $\begin{array}{l}\text { The Brief } \\
\text { Medication } \\
\text { Questionnaire } \\
\text { (BMQ) }\end{array}$ & $\begin{array}{l}\text { 5-item in } \\
\text { the } \\
\text { regimen } \\
\text { screen } \\
\text { 2-item in } \\
\text { the belief } \\
\text { screen } \\
\text { 2-item in } \\
\text { the recall } \\
\text { screen }\end{array}$ & $\begin{array}{l}43 \text { patients }(60 \% \text { were } \\
\text { males), their mean age }= \\
52.6\end{array}$ & $\begin{array}{l}\alpha=0.66 \text { (according to } \\
\text { a follow-up study that } \\
\text { assess the internal } \\
\text { consistency for the } \\
\text { BMQ) }{ }^{42}\end{array}$ & $\begin{array}{l}\text { All of the sensitivity findings were } \\
\text { for detecting repeat non-adherence } \\
0.8 \text { for the regimen screen } \\
1.0 \text { for belief screen } \\
0.4 \text { for the recall screen }\end{array}$ & $\begin{array}{l}\text { All of the } \\
\text { specificity } \\
\text { findings } \\
\text { were for } \\
\text { detecting } \\
\text { repeat non- } \\
\text { adherence } \\
1.0 \text { for the } \\
\text { regimen } \\
\text { screen } \\
0.8 \text { for belief } \\
\text { screen } \\
0.4 \text { for the } \\
\text { recall screen }\end{array}$ & Not reported ${ }^{41}$ & $\begin{array}{l}\text { Electronic monitoring devices } \\
\text { (the medication event } \\
\text { monitoring system MEMS) }\end{array}$ & USA & [26] \\
\hline
\end{tabular}




\begin{tabular}{|c|c|c|c|c|c|c|c|c|c|}
\hline $\begin{array}{l}\text { Hill- Bone } \\
\text { Compliance } \\
\text { Scale }\end{array}$ & 14 items & $\begin{array}{l}\text { In study } 1,309 \text { men, their } \\
\text { mean age }=41.3(S D= \\
5.3) \\
\text { In study } 2,718 \text { patients } \\
\text { ( } 30.8 \text { were males), their } \\
\text { mean age }=59.2(S D= \\
\text { 13.1) }\end{array}$ & $\begin{array}{l}\alpha=0.74 \text { (in study 1) } \\
\alpha=0.84 \text { (in study 2) }\end{array}$ & Not reported ${ }^{41}$ & $\begin{array}{l}\text { Not } \\
\text { reported }{ }^{41}\end{array}$ & 5 minutes & $\begin{array}{l}\text { Clinical outcome (blood } \\
\text { pressure) }^{41}\end{array}$ & USA & [33] \\
\hline $\begin{array}{l}\text { Medication } \\
\text { Adherence } \\
\text { Rating Scale } \\
\text { (MARS) }\end{array}$ & $\begin{array}{l}10 \text { yes or } \\
\text { no items }\end{array}$ & $\begin{array}{l}66 \text { patients ( } 51 \text { women } \\
\text { and } 15 \text { men), their mean } \\
\text { age }=32.89 \text { years (SD = } \\
\text { II.07) }\end{array}$ & $\begin{array}{l}\alpha=0.75 \\
\text { Test- retest reliability } \\
\text { (after } 2 \text { weeks) } \\
\alpha=0.72\end{array}$ & Not reported ${ }^{22,41}$ & $\begin{array}{l}\text { Not } \\
\text { reported } 22,41\end{array}$ & Not reported ${ }^{41}$ & $\begin{array}{l}\text { Multitrait-multimethod matrix } \\
\text { (drug level and caregiver } \\
\text { report) }\end{array}$ & Australia & [3I] \\
\hline $\begin{array}{l}\text { Medication } \\
\text { Adherence } \\
\text { Report Scale } \\
\text { for Asthma } \\
\text { (MARS-A) }\end{array}$ & 10 items & $\begin{array}{l}318 \text { patients with } \\
\text { persistent } \\
\text { Asthma ( } 83 \% \text { were } \\
\text { females), their mean age } \\
=48 \text { years ( }(\mathrm{D}=13) \\
245 \text { patients completed } \\
\text { the 3-month follow-up }\end{array}$ & $\begin{array}{l}\alpha=0.85 \\
\text { Test- retest reliability } \\
r=0.65\end{array}$ & 0.824 & 0.694 & Not reported & Electronic monitoring devices & USA & [34] \\
\hline $\begin{array}{l}\text { Personal } \\
\text { Evaluation of } \\
\text { Transitions in } \\
\text { Treatment } \\
\text { (PETiT) }\end{array}$ & 30 items & $\begin{array}{l}335 \text { schizophrenic } \\
\text { patients }(62.4 \% \text { were } \\
\text { males), their mean age = } \\
35.33 \text { years }(S D=12.12)\end{array}$ & $\begin{array}{l}\alpha=0.92 \\
\text { Split half reliability } \\
\text { (spearman- Brown } \\
\text { coefficient }=0.85 \text { ) }\end{array}$ & Not reported & $\begin{array}{l}\text { Not } \\
\text { reported }\end{array}$ & 2-5 minutes & $\begin{array}{l}\text { By using some other clinical and } \\
\text { quality of life measures (positive } \\
\text { and negative syndrome scale } \\
\text { PANSS, global assessment scale of } \\
\text { functioning GAF, and quality of life } \\
\text { scale QLS) }\end{array}$ & Canada & [25] \\
\hline $\begin{array}{l}\text { Pediatric } \\
\text { Inhaler } \\
\text { Adherence } \\
\text { Questionnaire } \\
\text { (PIAQ) }\end{array}$ & 6 items & $\begin{array}{l}\text { Parents or caregiver of } \\
64 \text { children with asthma, } \\
\text { their mean age }=3.6 \\
\text { years }(S D=2.2)\end{array}$ & $\begin{array}{l}\text { Not reported }{ }^{41} \\
\text { Test- retest reliability } \\
\text { Lin }\left(r_{c}\right) \text { concordance } \\
\text { correlation coefficient = } \\
0.82 \\
\text { Intraclass correlation = } \\
0.83\end{array}$ & $0.63^{41}$ & $0.9^{41}$ & I-3 minutes & $\begin{array}{l}\text { Dose count (canister weight } \\
\text { change) }\end{array}$ & Colombia & [30] \\
\hline $\begin{array}{l}\text { Self-efficacy } \\
\text { for } \\
\text { Appropriate } \\
\text { Medication } \\
\text { Use Scale } \\
\text { (SEAMS) }\end{array}$ & 13 items & $\begin{array}{l}436 \text { patients with } \\
\text { coronary heart disease } \\
\text { and other comorbid } \\
\text { conditions ( } 55.7 \% \text { were } \\
\text { females), their mean age } \\
=63.8(\mathrm{SD}=10.4)\end{array}$ & $\begin{array}{l}\alpha=0.89 \\
\text { Test- retest reliability } \\
\text { Spearman's } \rho=0.57\end{array}$ & Not reported ${ }^{22,41}$ & $\begin{array}{l}\text { Not } \\
\text { reported }{ }^{22,41}\end{array}$ & Not reported ${ }^{4}$ & $\begin{array}{l}\text { Medication Adherence } \\
\text { Questionnaire (MAQ) scale }\end{array}$ & Georgia & [36] \\
\hline
\end{tabular}


Table I (Continued).

\begin{tabular}{|c|c|c|c|c|c|c|c|c|c|}
\hline $\begin{array}{l}\text { Questionnaire } \\
\text { Name }\end{array}$ & $\begin{array}{l}\text { Number } \\
\text { of Items }\end{array}$ & Sample Size & Reliability & Sensitivity & Specificity & $\begin{array}{l}\text { Questionnaire } \\
\text { Completion } \\
\text { Time }\end{array}$ & Criterion Validation & Country & $\begin{array}{l}\text { Primary } \\
\text { Reference }\end{array}$ \\
\hline $\begin{array}{l}\text { The Brief } \\
\text { Adherence } \\
\text { Rating Scale } \\
\text { (BARS) }\end{array}$ & 4 items & $\begin{array}{l}61 \text { patients ( } 35 \text { with } \\
\text { schizophrenia, and } 26 \\
\text { with schizoaffective } \\
\text { disorder; } 50.8 \% \text { were } \\
\text { females), their mean age } \\
44.3(\mathrm{SD}=9.1 \text { ) }\end{array}$ & $\begin{array}{l}\alpha=0.92 \\
\text { Test- retest reliability } \\
\text { robust regression } \\
\text { coefficient ranged from } \\
0.53 \text { to } 0.92 \text { and } \\
\text { Spearman correlation } \\
\text { ranged from } 0.46 \text { to } \\
0.86\end{array}$ & 0.73 & 0.74 & $\begin{array}{l}\text { Less than } 5 \\
\text { minutes }\end{array}$ & $\begin{array}{l}\text { Using electronic monitoring } \\
\text { devices (MEMS) }\end{array}$ & USA & [24] \\
\hline $\begin{array}{l}\text { The } \\
\text { Adherence to } \\
\text { Refills and } \\
\text { Medications } \\
\text { Scale (ARMS) }\end{array}$ & 12 items & $\begin{array}{l}435 \text { patients with } \\
\text { coronary heart disease } \\
\text { ( } 55.6 \% \text { were females), } \\
\text { their mean age }=63.7 \\
(\mathrm{SD}=10.3)\end{array}$ & $\begin{array}{l}\alpha=0.814 \\
\text { Test- retest reliability } \\
\text { spearman's rho }=0.693\end{array}$ & Not reported ${ }^{41}$ & $\begin{array}{l}\text { Not } \\
\text { reported }^{41}\end{array}$ & Not reported ${ }^{41}$ & $\begin{array}{l}\text { I.Clinical outcome (blood } \\
\text { pressure) } \\
\text { 2.Pharmacy record- MAQ scale }\end{array}$ & USA & [29] \\
\hline $\begin{array}{l}\text { The Test of the } \\
\text { Adherence to } \\
\text { Inhalers (TAI) }\end{array}$ & 12 items & $\begin{array}{l}1009 \text { patients with } \\
\text { asthma or COPD }(56 \% \\
\text { were males), their mean } \\
\text { age }=58.0(S D=16.3)\end{array}$ & $\begin{array}{l}\alpha=0.86 \\
\alpha=0.873 \text { (for the } 10 \\
\text { item patient domain) } \\
\text { Test- retest reliability } \\
\alpha=0.883\end{array}$ & $\begin{array}{l}0.674 \text { (when the cut-off was } 50 \text { ) } \\
0.848 \text { (when the cut-off score was } \\
45 \text { ) } \\
\text { *Sensitivity and specificity of TAI } \\
\text { were assessed based on identifying } \\
\text { the groups of adherent (cut off TAl } \\
\text { score }=50 \text { ), intermediate adherent } \\
(46-49) \text { and non-adherent patients } \\
(\leq 45)\end{array}$ & $\begin{array}{l}0.660 \text { (when } \\
\text { the cut-off } \\
\text { was } 50 \text { ) } \\
0.226 \text { (when } \\
\text { the cut-off } \\
\text { score was } \\
45 \text { ) }\end{array}$ & $\begin{array}{l}\text { Around } 5 \\
\text { minutes }\end{array}$ & $\begin{array}{l}\text { I.Electronic monitoring devices } \\
\text { (Smart-inhalers) } \\
\text { 2.Morisky-Green questionnaire. }\end{array}$ & Spain & {$[27,35]$} \\
\hline
\end{tabular}


outcome. ${ }^{22}$ It is sensitive, brief, has the ability to discover different types of non-adherence, identify barriers, and evaluate multidrug regimen. ${ }^{22,32}$ On the other hand, it is difficult to score, a long time is needed to complete it, and patients are required to list their medication regimen as it assumes that this regimen is comprehensive. ${ }^{22}$

\section{The Hill-Bone Compliance Scale}

The Hill-Bone Compliance Scale was developed based on literature review and clinical expertise, it is used to assess patients' behaviors for three important behavioral domains (reduced sodium intake, appointment keeping, and medication taking) of high blood pressure treatment. ${ }^{33}$ It can identify barriers and assess self-efficacy, and it is suitable for low literacy patients $\left(5^{\text {th }}\right.$ grade) ${ }^{22,33}$ however, it focuses on hypertension patients limiting its generalizability. ${ }^{33}$

\section{The Medication Adherence Rating Scale (MARS)}

The MARS was developed based on the Medication Adherence Questionnaire (MAQ) and the DAI, it is a specific questionnaire instrument used for psychiatric patients. It can identify barriers, and it has an adequate reliability. However, it has a weak to moderate validity and it is limited in generalizability. ${ }^{22,31}$

\section{The Medication Adherence Report Scale for Asthma (MARS-A)}

The MARS-A is a self-reported measure of adherence to inhaled corticosteroids among patients with asthma. ${ }^{34}$ It does not assess the patient's inhalation technique because the questionnaire instrument is self-administered. Sometimes the patient may be confused by the way in which the questions are written. ${ }^{27}$

\section{The Personal Evaluation of Transitions in Treatment Questionnaire (PETiT)}

The PETiT was developed based on literature review, consultation with experts, individual interviews with patients and caregivers, and patients' focus groups, it is a scale used to capture aspects of subjective responses to, and tolerability of, antipsychotic drugs, treatment adherence, and impact of antipsychotic drug therapy on the quality of individuals treated for schizophrenia. ${ }^{25}$

\section{The Pediatric Inhaler Adherence Questionnaire (PIAQ)}

The PIAQ was developed based on literature review, expertise and focus groups, it is used to permits quantitative assessment of metered-dose inhaler adherence in children with asthma. ${ }^{30}$

\section{The Self-Efficacy Appropriate Medication Use Scale (SEAMS)}

The SEAMS was developed based on literature review, expertise and patient interviews, it provides a valuable assessment of medication self-efficacy in chronic disease management, it is a valid and reliable instrument used to measure self-efficacy, can identify barriers, and is suitable for several levels of patient literacy. ${ }^{22}$ However, it is difficult to score, and it has limited generalizability. ${ }^{22,36}$

\section{The Brief Adherence Rating Scale (BARS)}

The BARS was developed based on the lengthier adherence questionnaire used in the CATIE trial, it also has a visual analog rating scale $(0 \%-100 \%)$. It is a brief medication adherence instrument designed to assess oral antipsychotic medication adherence of outpatients with schizophrenia or schizoaffective disorders. The study conducted looking at its validity was brief, with a modest sample size, limiting the generalizability of the results. ${ }^{24}$

\section{The Adherence to Refills and Medications Scale (ARMS)}

The ARMS was developed based on literature review, MAQ, and Hill-Bone Compliance Scale, it is a medication adherence scale used in chronic disease populations and it is suitable for several levels of patient literacy. ${ }^{29}$ 


\section{The Test of the Adherence to Inhalers (TAI)}

The TAI was developed based on literature review and suggestions of the study scientific committee, it is an instrument that can identify non-adherence related to the use of inhalers in asthma and COPD patients. It can classify barriers from a clinical perspective. ${ }^{35}$

\section{Component Analysis for the Adherence Questionnaire Instruments}

For all of the identified instruments, the factors it contained accounted together for a total variance that ranges from $45 \%$ (ARMS) to $89 \%$ (MARS-A). ${ }^{29,34}$

For DAI, Exploratory Factor Analysis (EFA) was used to evaluate the underlying internal structure for some variables and uncover the relationship between them. ${ }^{29}$ Seven factors emerged from the DAI, labeled as 1. positive subjective attitudes, 2. negative subjective attitudes, 3. health/illness, 4. physician, 5. control, 6. prevention, and 7. harm. Factor 1 accounted for $59.8 \%$ of the total variance while factor 2 accounted for $11.7 \%$. Thus, the first two factors accounted for almost $3 / 4$ of the variance and reflected patients' experiences of medication use. The five remaining factors reflected attitudes or beliefs. Factor 3 reflected the patient's model of health. Factor 4 and 5 reflected patient's control in taking his/her medication. Factor 6 reflected patient beliefs about the effect of medication use. Factor 7 reflected concerns about potential side effects. ${ }^{28}$

For the Morisky questionnaire instrument, The principal component analysis identified only a single factor confirming the unidimensionality of the scale. ${ }^{23}$

For Hill-Bone Compliance Scale, two studies were done to conduct the principal component analysis for this questionnaire instrument; five factors were extracted from the first study, and four factors from the second study. ${ }^{33}$

For MARS, factor analysis highlighted three factors, the first factor represented medication adherence behavior and accounted for $32 \%$ of the variance, the second factor represented subjects' attitude to taking the medication and accounted for $16 \%$ of the variance, and the third factor represented negative side effects and attitudes to psychotropic medication and accounted for $12 \%$ of the variance. All these factors together accounted for $59 \%$ of the total variance. ${ }^{31}$

For MARS-A, the principal component analysis showed that $89 \%$ of the variance was due to one factor only, suggesting that MARS-A can only measure adherence. ${ }^{34}$

For PETiT, construction of it yielded 12 themes that were identified as relevant domains. Factor analysis confirmed the robustness of the initial construct. ${ }^{25}$

For SEAMS questionnaire instrument, two dimensions were revealed by the factor analysis; factor one represented self-efficacy for taking medications under difficult circumstances and accounted for $45 \%$ of the variance, while factor two represented self-efficacy for continuing to take medications when circumstances surrounding medication-taking were uncertain and accounted for $8 \%$ of the variance. In the analysis of this study, any item that loaded 0.4 or more was considered to measure a factor. Of noteworthy, one item in the SEAMS questionnaire loaded more than 0.4 on both factors, and it was decided to add it to factor one because it agreed more conceptually with that factor, so it was grouped according to interpretability rather than the highest loading outcome. ${ }^{36}$

In ARMS, a two-factor solution was forced and the items clustered as expected. The first factor contained eight items related to taking medications as prescribed and explained $35 \%$ of the variance, while the other factor contained four items related to refilling medications on schedule and explained $10 \%$ of the variance. ${ }^{29}$

For TAI, a factor analysis highlighted two domains, the patient domain and the healthcare professional domain. The two domains explained $51 \%$ of the total variance of the results. ${ }^{35}$

\section{Discussion}

Medication adherence is a dynamic process that has various patterns at consecutive time points, and it is critical to provide optimal medication management. ${ }^{37}$ Adherence to treatment has been studied extensively and collated findings of such research indicate that a low level of adherence can increase mortality and morbidity rates, in addition to healthcare costs. ${ }^{38,39}$ Assessing adherence to medications is considered to be an essential step to guide adherence enhancing interventions. ${ }^{40}$ However, sometimes it is difficult for clinicians to easily identify patients who are nonadherent. Thus, self-reported medication adherence instruments can be used as a tool to identify nonadherent patients. Furthermore, self-reports remain the most appropriate, available, accessible, 
cheap, useful, and practical method to assess patient's adherence to medication which can be used routinely. ${ }^{9,15}$ Ideally, a selfreport adherence tool must be brief, reliable, and valid. ${ }^{15}$ Reviewing the instrument characteristics such as the number of the items in the instrument, the sample size, reliability, sensitivity, specificity, questionnaire completion time, and criterion validity is important when selecting a tool to use at the point of care.

The difference between the methodologies used in the different adherence instruments development regarding the test-retest reliability assessment presents a barrier for the reader to compare and contrast the utility of the different instruments developed. It is recommended for researchers to unify the methodology of assessment used in the future. Considering the fact that most researchers based this analysis on the two weeks difference period of assessment, we propose for all future questionnaire instruments development to be based on this type of assessment.

Pharmacists can offer numerous services that contribute to increasing patient adherence since data from different research showed a positive association between pharmacists and patient adherence to medication; a link for teamwork between the pharmacists and the patients is needed. This link can be a validated instrument to assess patient's adherence found in every pharmacy. More studies are needed hoping that the results of these studies will help in providing a better contribution of pharmacists in patient's treatment.

\section{Conclusion}

Various questionnaire instruments can be used to assess patient's adherence to medications, however, no single one performs well on all criteria. A particular instrument can be used as an indicator of non-adherence to medications after considering some criteria such as the specific requirements, population, and the available time of administration.

There is a recognized need to form primary care medication adherence services that are customized to patient's needs. Continuous quality enhancement of such services needs a regular working method of measuring adherence to monitoring the effectiveness of treatment. This presents an important and exciting avenue for further research.

\section{Author Contributions}

All authors made a significant contribution to the work reported, whether that is in the conception, study design, execution, acquisition of data, analysis and interpretation, or in all these areas; took part in drafting, revising or critically reviewing the article; gave final approval of the version to be published; have agreed on the journal to which the article has been submitted; and agree to be accountable for all aspects of the work.

\section{Funding}

This research did not receive any specific grant from funding agencies in the public, commercial, or not-for-profit sectors.

\section{Disclosure}

The authors declare no relevant conflicts of interest or financial relationships.

\section{References}

1. Lee J, Tay TR, Radhakrishna N, et al. Non-adherence in the era of severe asthma biologics and thermoplasty. Eur Respir J. 2018;51(4):1701836. doi:10.1183/13993003.01836-2017

2. De Geest S, Sabaté E. Adherence to Long-Term Therapies: Evidence for Action: World Health Organization. Vol. 2. 2003.

3. Vrijens B, De Geest S, Hughes DA, et al. A new taxonomy for describing and defining adherence to medications. Br J Clin Pharmacol. 2012;73 (5):691-705. doi:10.1111/j.1365-2125.2012.04167.x

4. Donner CF, Amaducci S, Bacci E, et al. Inhalation therapy in the next decade: determinants of adherence to treatment in asthma and COPD. Int J Cardiopulm Med Rehabil. 2018;1:88.

5. Bae SG, Kam S, Park KS, et al. Factors related to intentional and unintentional medication nonadherence in elderly patients with hypertension in rural community. Patient Prefer Adherence. 2016;10:1979-1989.

6. Náfrádi L, Galimberti E, Nakamoto K, Schulz PJ. Intentional and Unintentional Medication Non-Adherence in Hypertension: the Role of Health Literacy, Empowerment and Medication Beliefs. J Public Health Res. 2016;5:847.

7. Brown MT, Bussell JK. Medication Adherence: WHO Cares? Mayo Clin Proc. 2011;86(4):304-314. doi:10.4065/mcp.2010.0575

8. Iuga AO, Mcguire MJ. Adherence and health care costs. Risk Manag Healthc Policy. 2014;7:35-44. doi:10.2147/RMHP.S19801

9. Dima AL, Van GE, Laforest L, Texier N, Bruin M, ASTRO-LAB Group T. Measuring medication adherence in asthma: development of a novel self-report tool. Psychol Health. 2017;32(10):1288-1307. doi:10.1080/08870446.2017.1290248 
10. Taylor TE, Zigel Y, De LC, Sulaiman I, Costello RW, Reilly RB. Advances in Audio-Based Systems to Monitor Patient Adherence and Inhaler Drug Delivery. Chest J. 2017;153(3):710-722. doi:10.1016/j.chest.2017.08.1162

11. Locatelli I, Kos M, Kos M. Criterion validity of 8-item Morisky Medication Adherence Scale in patients with asthma. PLoS One. $2017 ; 12$. doi:10.1371/journal.pone. 0187835

12. Anghel LA, Farcas AM, Oprean RN. An overview of the common methods used to measure treatment adherence. Med Pharm Reports. 2019;92 (2): 117.

13. Vitolins MZ, Rand CS, Rapp SR, Ribisl PM, Sevick MA. Measuring adherence to behavioral and medical interventions. Control Clin Trials. 2000;21(5):S188-S194. doi:10.1016/S0197-2456(00)00077-5

14. Stirratt MJ, Dunbar-jacob J, Crane HM, et al. Self-report measures of medication adherence behavior: recommendations on optimal use. TBM Pract PUBLIC Heal POLICIES. 2015;5(4):470.

15. Garfield S, Clifford S, Eliasson L, Barber N, Willson A. Suitability of measures of self-reported medication adherence for routine clinical use: a systematic review. BMC Med Res Methodol. 2011;11(149). doi:10.1186/1471-2288-11-149

16. Monnette A, Zhang Y, Shao H, Shi L. Concordance of Adherence Measurement Using Self-Reported Adherence Questionnaires and Medication Monitoring Devices: an Updated Review. Pharmacoeconomics. 2017;1:36.

17. Readdean KC, Parrott JS, Heuer AJ. Effect of pharmacist intervention on improving antidepressant medication adherence and depression symptomology: a systematic review and meta-analysis. Res Soc Adm Pharm. 2018;14(4):321-331. doi:10.1016/j.sapharm.2017.05.008

18. Bubalo J, Jr RKC, Jiing SS, et al. Medication adherence: pharmacist perspective. J Am Pharm Assoc. 2010;50(3):394-406. doi:10.1331/ JAPhA.2010.08180

19. Abughosh SM, Wang X, Serna O, et al. A pharmacist telephone intervention to identify adherence barriers and improve adherence among nonadherent patients with comorbid hypertension and diabetes in a medicare advantage plan. J Manag Care Spec Pharm. $2016 ; 22(1): 117$.

20. Milosavljevic A, Aspden T, Harrison J. Community pharmacist-led interventions and their impact on patients' medication adherence and other health outcomes: a systematic review. Int J Pharm Pract. 2018;26(5):387-397. doi:10.1111/ijpp.12462

21. Kini V, Ho M. Interventions to Improve Medication Adherence A Review. JAMA - J Am Med Assoc. 2018;320(23):2461. doi:10.1001/ jama.2018.19271

22. Lavsa SM, Holzworth A, Ansani NT. Selection of a validated scale for measuring medication adherence. J Am Pharm Assoc. 2011;51(1):90-94. doi:10.1331/JAPhA.2011.09154

23. Morisky DE, Green LW, Levine DM. Concurrent and predictive validity of a self-reported measure of medication adherence. Med Care. 1986;24 (1):67-74. doi:10.1097/00005650-198601000-00007

24. Byerly MJ, Nakonezny PA, Rush AJ. The Brief Adherence Rating Scale (BARS) validated against electronic monitoring in assessing the antipsychotic medication adherence of outpatients with schizophrenia and schizoaffective disorder. Schizophr Res. 2008;100(1-3):60-69. doi:10.1016/j.schres.2007.12.470

25. Voruganti LNP, Awad AG. Personal evaluation of transitions in treatment (PETiT): a scale to measure subjective aspects of antipsychotic drug therapy in schizophrenia. Schizophr Res. 2002;56(1-2):37-46. doi:10.1016/S0920-9964(01)00161-X

26. Svarstad BL, Chewing BA, Sleath BL, Claesson C. The brief medication questionnaire: a tool for screening patient adherence and barriers to adherence. Patient Educ Couns. 1999;37(2):113-124. doi:10.1016/S0738-3991(98)00107-4

27. Plaza V. Update on questionnaires for assessing adherence to inhaler devices in respiratory patients. Curr Opin Allergy Clin Immunol. 2017;18 (1):44-46.

28. Hogan TP, Awad AG, Eastwood R. A self-report scale predictive of drug compliance in schizophrenics: reliability and discriminative validity. Psychol Med. 1983;13(1):177-183. doi:10.1017/S0033291700050182

29. Kripalani S, Risser J, Gatti ME, Jacobson TA. Development and Evaluation of the Adherence to Refills and Medications Scale (ARMS) among Low-Literacy Patients with Chronic Disease. Value Heal. 2009;12(1):118-123. doi:10.1111/j.1524-4733.2008.00400.x

30. Martinez CE, Sossa MP, Rand CS. Validation of a Questionnaire for Assessing Adherence to Metered-Dose Inhaler Use in Asthmatic Children. Pediatr Asthma Allergy Immunol. 2007;20(4):243-254. doi:10.1089/pai.2007.001

31. Thompson K, Kulkarni J, Sergejew AA. Reliability and validity of a new Medication Adherence Rating Scale (MARS) for the psychoses. Schizophr Res. 2000;42(3):241-247. doi:10.1016/S0920-9964(99)00130-9

32. Lam WY, Fresco P. Medication Adherence Measures: an Overview. Biomed Res Int. 2015;2015:1-12. doi:10.1155/2015/217047

33. Kim MT, Hill MN, Bone LR, Levine DM. Development and Testing of the Hill-Bone Compliance to High Blood Pressure Therapy Scale. Prog Cardiovasc Nurs. 2000;15(3):90-96. doi:10.1111/j.1751-7117.2000.tb00211.x

34. Cohen JL, Mann DM, Wisnivesky JP, et al. Assessing the validity of self-reported medication adherence among inner-city asthmatic adults: the Medication Adherence Report Scale for Asthma. Ann Allergy, Asthma Immunol. 2009;103(4):325-331. doi:10.1016/S1081-1206(10)60532-7

35. Plaza V, Fernandez-Rodríguez C, Melero C, et al. Validation of the 'Test of the Adherence to Inhalers' (TAI) for asthma and COPD patients. J Aerosol Med Pulm Drug Deliv. 2015;29(2):84.

36. Risser J, Jacobson TA, Kripalani S. Development and Psychometric Evaluation of the Self-Efficacy for Appropriate Medication Use Scale (SEAMS) in Low-Literacy Patients With Chronic Disease. J Nurs Meas. 2007;15(3):203-219. doi:10.1891/106137407783095757

37. Blaschke TF, Osterberg L, Vrijens B, Urquhart J. Adherence to Medications: insights Arising from Studies on the Unreliable Link Between Prescribed and Actual Drug Dosing Histories. Annu Rev Pharmacol. 2012;52(1):275-301. doi:10.1146/annurev-pharmtox-011711-113247

38. Timmerman L, Stronks DL, Groeneweg JG, Huygen FJ. Prevalence and determinants of medication non-adherence in chronic pain patients: a systematic review. Acta Anaesthesiol Scand. 2016;60(4):416-431. doi:10.1111/aas.12697

39. Souverein PC, Koster ES, Colice G, et al. Inhaled Corticosteroid Adherence Patterns in a Longitudinal Asthma Cohort. J Allergy Clin Immunol Pract. 2017;5(2):448-456.e2. doi:10.1016/j.jaip.2016.09.022

40. Rand CS, Wise RA. Measuring Adherence to Asthma Medication Regimens. Am J Respir Crit Care Med. 1994;149(2):S69-S76. doi:10.1164/ ajrccm/149.2_Pt_2.S69

41. Nguyen T, La CA, Cottrell N. What are validated self-report adherence scales really measuring?: a systematic review. Br J Clin Pharmacol. 1999;77(3):38.

42. Ben AJ, Neumann CR, Mengue SS. The Brief Medication Questionnaire and Morisky-Green test to evaluate medication adherence. Rev Saude Publica. 2012;46(2):279-289. doi:10.1590/S0034-89102012005000013 


\section{Publish your work in this journal}

Patient Preference and Adherence is an international, peer-reviewed, open access journal that focusing on the growing importance of patient preference and adherence throughout the therapeutic continuum. Patient satisfaction, acceptability, quality of life, compliance, persistence and their role in developing new therapeutic modalities and compounds to optimize clinical outcomes for existing disease states are major areas of interest for the journal. This journal has been accepted for indexing on PubMed Central. The manuscript management system is completely online and includes a very quick and fair peer-review system, which is all easy to use. Visit http://www.dovepress.com/testimonials.php to read real quotes from published authors.

Submit your manuscript here: https://www.dovepress.com/patient-preference-and-adherence-journal 